УДК 637.02

DOI https://doi.org/10.15673/swonaft.v85i1.2075

\title{
ЗАСТОСУВАННЯ АБСОРБЦІЙНОЇ ІЧ - СПЕКТРОСКОПІї ДЛЯ ВИЯВЛЕННЯ СКЛАДУ ДИМО-ПОВІТРЯНОЇ СУМІШІ ГОРІННЯ ДЕРЕВИНИ ПРИ КОПЧЕННІ М'ЯСНИХ ВИРОБІВ
}

\author{
Ощипок І. М., д-р техн. наук, професор \\ Львівський торговельно-економічний університет, м. Львів
}

\begin{abstract}
В статті досліджені перспективи виявлення вмісту димо-повітряних компонентів в повітрі, щзо утворюються при спалюванні деревини. Розглянуті задачі з детектування слідів газоподібних речовин в локальній зоні повітряного середовища. Дане завдання відноситься до числа найбільш складних завдань газового аналізу, що обумовлюється малими кониентраціями шуканих речовин і навпаки, високим вмістом сполук, щьо перешкоджають аналізу. Звернута увага на інтерпретаџіï IЧ спектрів, які полягають у тому, шзо враховується не тільки положення максимумів характеристичних смуг, але $і$ на ї інтенсивності, формі, розташуванню щзодо інших смуг. Про природу і кількість речовини в димо-повітряної суміші можна судити відповідно по числу і положенню піків в ІЧ-спектрах поглинання (якісний аналіз), а за інтенсивністю циих смуг про кількість речовини (кількісний аналіз). Поліпшення чутливості і селективності методу можливе шляхом підвищення роздільної здатності приладів, а також використання різних прийомів формування та обробки аналізованого сигналу. Одним із прийомів формування аналізованого сигналу є диференційний метод. Використовуваний метод повинен бути високочутливим, точним, швидкодіючим і забезпечувати селективність виявлення складових димо-повітряної суміші, і може припускати роботу на деякій відстані. Розглянута ідея методу, яка полягає в одночасному пропусканні через димо-повітряну сумім, шо знаходиться в термокамері зондуючого випромінювання на двох довжинах хвиль, перша з яких збігається з максимумом смуги поглинання досліджуваної речовини, а друга так звана опорна до неї довжина хвилі, тобто довжина хвилі близька до зондуючої, але яка не лежить в смузі поглинання. Співвідношення сигналів на виході опорного і вимірювального каналів не залежить від стабільності джерела і приймача випромінювання.
\end{abstract}

Ключові слова: копчення, суміш, димо-повітряна, ІЧ спектроскопія, м'ясні, вироби

Постановка проблеми в загальному вигляді та зв'язок із найважливішими науковими чи практичними завданнями. Копчення є важливим способом консервування м'яса. Через процес копчення м'ясні продукти втрачають частково воду, отримують специфічний запах, збільшується тривалість їх зберігання, поліпшується присмак.

В результаті дії на продукт коптильних речовин, які отримані при неповному згоранні стружки деревини, досягається стійкість м'ясопродуктів до дії гнильної мікрофлори і значно затримується дія кисню повітря на жирову тканину приготовлених м'ясних виробів. Дія коптильних речовин має бактерицидні та антиокислювальні властивості. До складу коптильного диму входять альдегіди, кетони, спирти, органічні кислоти, феноли, тощо. Концентрація елементів диму змінюється залежно від температури тління деревини, ії властивості (вологовмісту) та умов отримання диму. Якщо формування диму залежить від вологості деревини коли подається невелика кількість повітря, то виходить густа, насичена волога, темного кольору димоповітряна суміш. При такій димо-повітряній суміші м'ясні вироби погано забарвлюються. Властивість отриманої димо-повітряної суміші на-самперед залежить від температури тління деревини, яка повинна бути забезпечена в діапазоні температур $250-350{ }^{\circ} \mathrm{C}$.

Шкідлива дія на організм людини деяких речовин, полягає в накопичені небезпечних компонентів диму: формальдегідів, які знижують активність травних ферментів, бензойної кислоти інгібуючої дію пепсину в шлунку, оцтової кислоти підвищуючої кислотність шлунково-кишкового каналу, поліциклічних ароматичних вуглеводів, маючих канцерогенні та мутагенні властивості.

Аналіз останніх досліджень і публікацій. На сьогодні застосовують деякі фізико-хімічні методи реєстрації якісного і кількісного складу димо-повітряної суміші, що утворюється при горінні деревини. До них можна віднести електрохімічні сенсори, оптичні датчики і ІЧ-спектроскопію. Методи на основі електрохімічних датчиків працюють на хімічні реакції аналізованого газу з електролітом, що приводить до виникнення заряджених йонів і електричного струму. Величина електричного струму пропорційна концентрації аналізованого компоненту в пробі. Існує два види газових датчиків, здатних виявляти домішки диму в повітряному середовищі - термохімічні і напівпровідникові. Термохімічні датчики застосовуються в основному для виявлення оксиду вуглецю (СО), але можливе їх застосування і для аналізу вмісту парів етанолу, так як вони реагують на всі горючі гази. Напівпровідникові датчики працюють за принципом зміни електричного опору деяких напівпровідникових матеріалів, що виникає в результаті адсорбції газу. При нагріванні напівпровідникового датчика до робочих температур (близько $400{ }^{\circ} \mathrm{C}$ ) за допомогою нагрівальної частини, яка виконана конструктивно з сенсором, відбувається абсорбція газоподібної контрольованої речовини яка міститься в 
повітрі на поверхні чутливого шару датчика, що має дрібнозернисту структуру. Ступінь абсорбції залежить від концентрації домішки в газі. В результаті поверхневих ефектів змінюється електрична провідність сенсора, тобто відгук датчика проходить через зміну опору залежно від концентрації газу, що змінює ступінь абсорбції на матеріалі датчика. Швидкість відгуку залежить від моделі датчика і конкретної домішки газу. До переваг напівпровідникових датчиків слід віднести їх невисоку вартість і просту схему включення. До недоліків - короткий час безперервної роботи (близько 1 року) внаслідок витрачання робочого шару, який входить у взаємодію з контрольованою речовиною, а також мала чутливість, низька селективність аналізу і достатньо високі значення температур, які не прийнятні при копченні м'ясних виробів. Робота оптичних датчиків відбувається на залежності ряду оптичних властивостей середовища, таких як коефіцієнт заломлення, коефіцієнт відображення і від концентрації кисню.

В роботах: $[1,2,6]$ - описані загальні методи атомно-абсорбційного спектроскопічного аналізу і вплив диму при консервуванні м'яса, $[3,4]$ - розглянуто застосування автоматизованих спектроенергетичних засобів в ближній інфрачервоній області спектру і практичне застосування ІЧ спектроскопії, [5] - досліджено застосування IЧ променів на відстані при проходженні через повітря, [7] - наведені дослідження IЧ спектрів основних класів органічних сполук, [8] - показані фенольні антиоксиданти в димі вільхи під час промислового консервування м’яса, [9] - визначені мінімальні допустимі концентрації рідких фракцій диму, [10, 11] надано інформацію про прозорість земної атмосфери і дані про хімічний склад речовин. Досліджень пов'язаних з застосуванням ІЧ-спектроскопії для виявлення складу димо-повітряної суміші при копченні не проводились.

Постановка завдання. При наявності в димо-повітряній суміші речовин з однаковими спектральними характеристиками проблема точного вимірювання якісного і кількісного складу досліджуваного середовища стає актуальною. Крім того, конструктивні і функціональні особливості оптичних і електрохімічних датчиків не дозволяють точно оцінювати концентрацію хімічних сполук, які утворюються, крім кисню і вуглекислого газу, а також вимагають наявності громіздкого обладнання для проведення досліджень. Найбільш підходящими для вирішення поставленого завдання є застосування абсорбційної ІЧ - спектроскопії, заснованої на існуванні певної функціональної залежності між концентрацією речовини в поглинаючому середовищі і одним з параметрів, що характеризує спектральну лінію поглинання [1]. Даний метод позбавлений недоліків вищеописаних способів, крім того він є безконтактним. ІЧ-випромінювання яке проходить через речовину поглинається на частотах, що збігається з власними коливальними і обертальними частотами молекул і коливань кристалічної решітки. В результаті інтенсивність інфрачервоного випромінювання на цих частотах падає - утворюються смуги поглинання. Даний метод проілюструємо на виявленні етанолу в димо- повітряній суміші при спалюванні деревини.

Виклад основного матеріалу дослідження. Довжина хвилі для кожного коливання залежить від того які атоми в ньому беруть участь, тобто для кожної функціональної групи характерні коливання певної довжини хвилі. За інфрачервоними спектрами поглинання можна встановити будову молекул різних органічних і неорганічних речовин з відносно короткими молекулами: антибіотиків, ферментів, алкалоїдів, полімерів та інших. Про природу і кількість речовини в димо-повітряної суміші можна судити відповідно по числу і положенню піків в ІЧ-спектрах поглинання (якісний аналіз), а за інтенсивністю цих смуг - про кількість речовини (кількісний аналіз). На рис. 1, 2 представлені інфрачервоні спектри поглинання етанолу $\left(\mathrm{C}_{2} \mathrm{H}_{5} \mathrm{OH}\right) \mathrm{i}$ аміаку $\left(\mathrm{NH}_{3}\right)$, який міститься в димо-повітряній суміші.

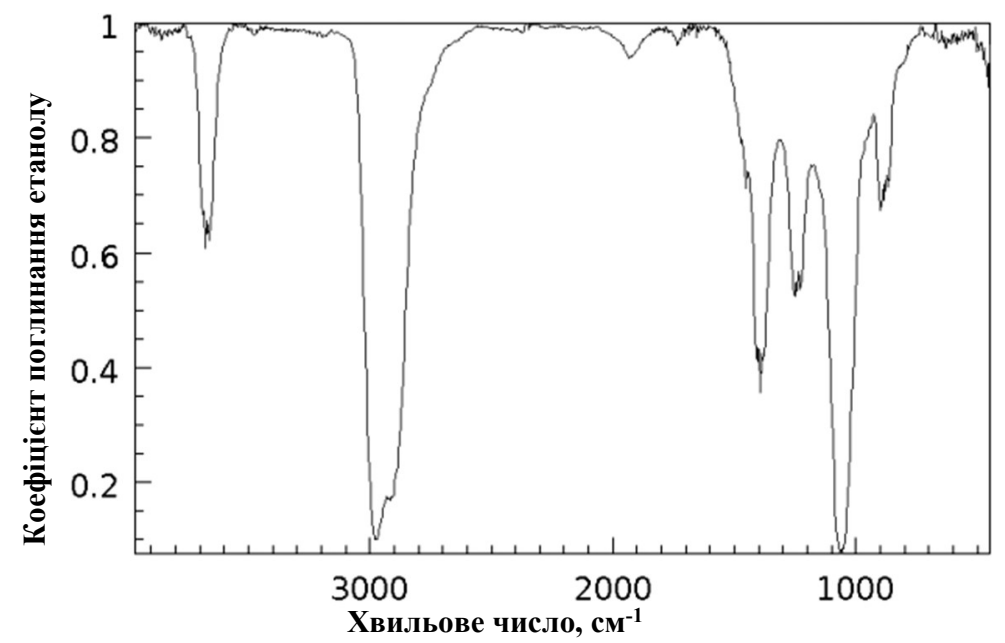

Рис.1 - ІЧ-спектри поглинання етанолу 


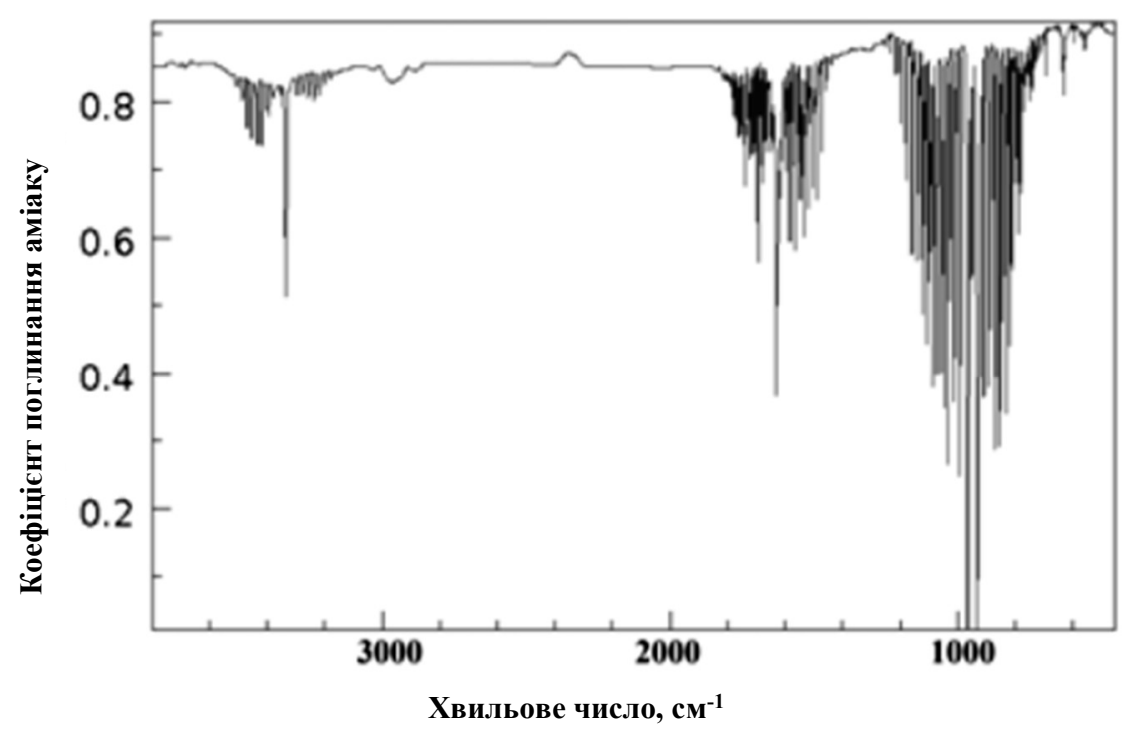

Рис.2 - ІЧ-спектри поглинання аміаку

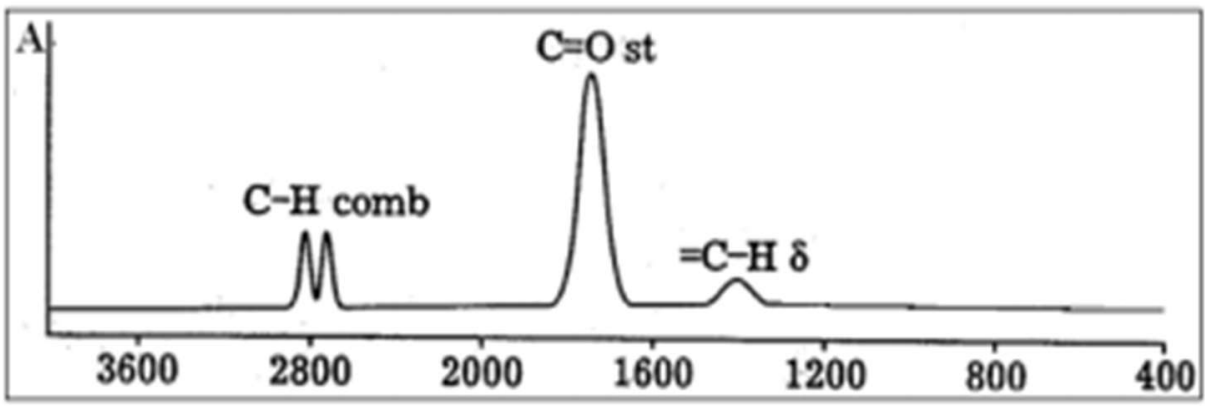

Рис. 3 - Графік ІЧ спектру альдегіду

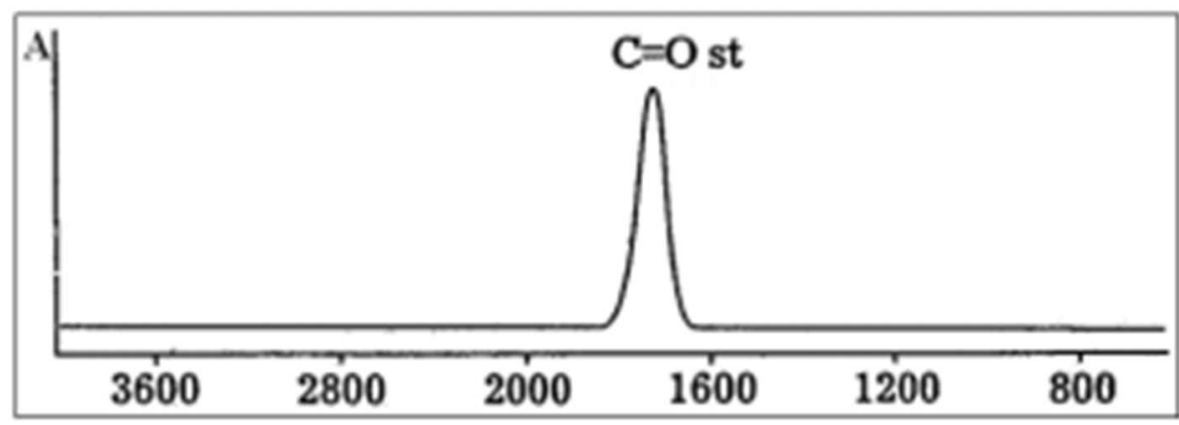

Рис. 4 - Графік ІЧ спектру кетону

На рис. 1 і 2 представлені інфрачервоні спектри поглинання етанолу $\left(\mathrm{C}_{2} \mathrm{H}_{5} \mathrm{OH}\right)$ та аміаку $\left(\mathrm{NH}_{3}\right)$ відповідно. 3 рисунків видно, що характеристичні смуги поглинання етанолу в ближньому ІЧ-спектрі лежать в області від 3600 до $3000 \mathrm{~cm}^{-1}$ (що відповідає діапазону довжин хвиль від 2,77 до 3,33 мкм), а аміаку - від 3800 до $3550 \mathrm{~cm}^{-1}$ (від 2,6 до 2,81 мкм). Для дослідження складу складних газових сумішей, до яких можна віднести димо- повітряну суміш, однією з головних проблем є вибір найбільш інформативної ділянки для аналізу спектра. Димо- повітряна суміш, містить значну кількість летких хімічних сполук, причому наявний вміст у ній молекул $\mathrm{H}_{2} \mathrm{O}, \mathrm{CO}$ i $\mathrm{CO}_{2}$ досить великий і може заважати аналізу. Тому важливими критеріями при виборі оптимальної довжини хвилі для дослідження є іiі інтенсивність, а також розташування ії в так званих «вікнах прозорості» в спектрах пропускання $\mathrm{H}_{2} \mathrm{O}, \mathrm{CO}$ і $\mathrm{CO}_{2}$ атмосферних газів.

Ідея методу полягає в одночасному пропусканні через димо-повітряну суміш, що знаходиться в термокамері зондуючого випромінювання на двох довжинах хвиль, перша з яких збігається з максимумом смуги поглинання досліджуваної речовини, а друга так звана опорна до неї довжина хвилі, тобто довжина хвилі близька до зондуючої, але не лежить в смузі поглинання. У досліджуваному обсязі димо-повітряної суміші втрати на розсіювання обох довжин хвиль будуть приблизно однаковими, а зниження інтенсивності відбитого випромінювання однієї з хвиль буде залежати від концентрації контрольованої речовини. Поглинання 
випромінювання в газі опишемо законом Бугера - Ламберта [4], згідно з яким щільність потоку енергії оптичного випромінювання, що пройшов через середовище яке досліджується змінюється за експоненціальним законом:

$$
I=I_{0} \cdot e^{-\mu_{a}(\lambda) \cdot d}
$$
$\mathrm{BT} / \mathrm{M}^{2}$

де $\mathrm{I}_{0}$ - щільність потоку випромінювання, який подається на поглинаюче середовище товщиною $\mathrm{d}$,

I - щільність потоку випромінювання, що пройшов через поглинаюче середовище, Вт/м²;

$\mu_{a}(\lambda)$ - спектральний коефіцієнт поглинання випромінювання, $\mathrm{cm}^{-1}$.

Для виключення впливу на результат вимірювання розсіюючих властивостей середовища, нестабільності джерела випромінювання та іншого запропонована двохвильова схема. Довжина хвилі другого (опорного) каналу не збігатиметься зі смугою поглинання контрольованої речовини, але знаходитиметься близько до неї. Співвідношення сигналів на виході опорного і вимірювального каналів не залежить від стабільності джерела і приймача випромінювання. Якщо опромінювати димо-повітряну суміш на опорній і вимірювальній довжинах хвиль, то пройшовши через неї потоки відповідно будуть рівні

$$
\begin{aligned}
& I_{\lambda_{0}}=k \cdot I_{0} \cdot e^{-\mu_{a}\left(\lambda_{0}\right) \cdot d} \\
& I_{\lambda_{0}}=k \cdot I_{0} \cdot e^{-\mu_{a}\left(\lambda_{u}\right) \cdot d-\mu_{a}\left(\lambda_{u}\right) \cdot d}
\end{aligned}
$$

де $\mathrm{k}$ - коефіцієнт передачі оптичного каналу, що враховує втрати енергії в ньому, посилення електронної схеми, чутливість приймача випромінювання,

$\mu_{a}\left(\lambda_{0}\right), \mu_{a}\left(\lambda_{u}\right)$ - коефіцієнти ослаблення випромінювання від джерела до приймача випромінювань;

' a $^{\prime}\left(\lambda_{u}\right)$ - коефіцієнт поглинання парів досліджуваної речовини в повітрі, що утворюється в його смузі поглинання.

Оскільки, $\lambda_{u} \cong \lambda_{0}$ то, $\mu_{a}\left(\lambda_{u}\right) \cong \mu_{a}\left(\lambda_{0}\right)$ логарифм відношення реєстрованих сигналів буде мати наступний вигляд:

$$
\ln \left(I_{\lambda_{u}} / I_{\lambda_{0}}\right)=-d \cdot \mu_{a}^{\prime}\left(\lambda_{u}\right)
$$

Коефіцієнт поглинання пов'язаний з концентрацією поглинаючого диму. Згідно із законом Бера - кожна молекула або атом незалежно від відносного розташування інших молекул або атомів поглинає одну і ту ж частку енергії випромінювання, тобто

$$
\mu_{a}^{\prime}=A \cdot C_{p}
$$

де А- молярний коефіцієнт поглинання, що характеризує поглинальні властивості речовини. Має розмірність л моль ${ }^{-1} \mathrm{~cm}^{-1}$;

$C_{p}$ - концентрація шуканої речовини, моль/л,

Отже:

$$
C_{p}=-\frac{\ln \left(I_{\lambda u} / I_{\lambda 0}\right)}{d \cdot A_{\lambda u}}
$$

Фізичний зміст А полягає в тому, що якщо прийняти $C_{p}=1$ моль/л $\mathrm{i} \mathrm{d}=1 \mathrm{~cm}$, то молярний коефіцієнт поглинання дорівнюватиме оптичній щільності одномолярного розчину (D) при товщині шару 1 см. Величина А залежить від довжини хвилі світла, що проходить, природи світлопоглинальної речовини і температури і не залежить від концентрації шуканої речовини, товщини поглинаючого шару і інтенсивності випромінювання. Оптична щільність дорівнює десятковому логарифму відношення потоку випромінювання $\mathrm{I}_{0}$, що падає на прошарок димо- повітряній суміші, до ослабленого в результаті поглинання і розсіяння потоку $\mathrm{I}_{\mathrm{u}}$, який пройшов через цей прошарок:

$$
D=\lg \left(I_{0} / I_{u}\right)
$$

Монохроматична оптична щільність прошарку не розсіюючого середовища (без урахування поправок на відбивання від передньої і задньої границі прошарку) дорівнює:

$$
D=0,4343 \cdot A \cdot C_{p} \cdot d
$$


В інфрачервоних спектрах оптична щільність поглинання етанолу лежить в області від 2,73 до 3,33 мкм (рис. 5.).

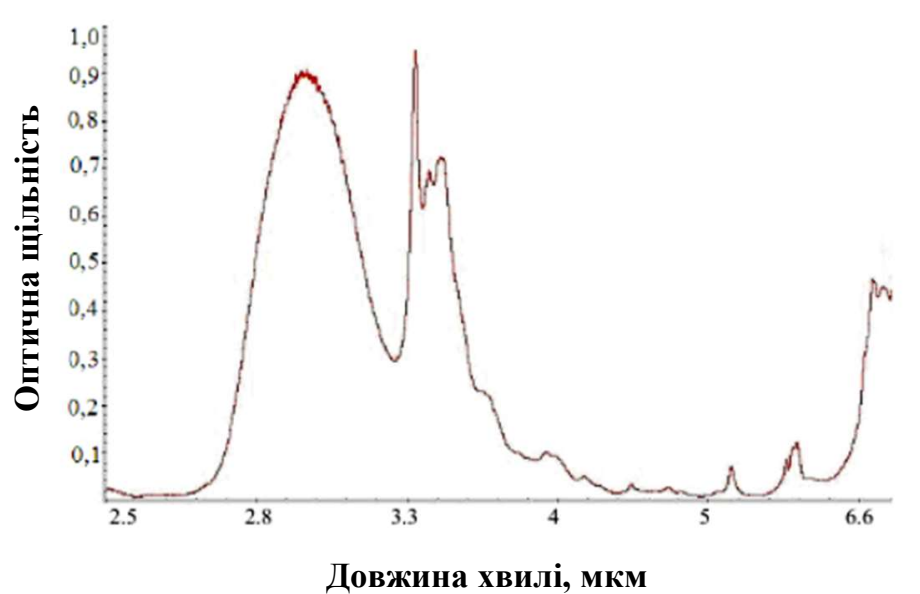

Рис. 5 - Оптична щільність поглинання етанолу

$$
\begin{aligned}
U_{\lambda u} & =U_{\lambda u} \pm \xi_{m} \\
U_{\lambda 0} & =U_{\lambda 0} \pm \xi_{m}
\end{aligned}
$$

3 урахуванням вище описаного, краще використовувати довжину хвиль 3,1 мкм (для етанолу) з огляду на більш сильне поглинання випромінювання досліджуваними речовинами, наявності в цьому діапазоні «вікна прозорості» атмосферних газів. На обраних довжинах хвиль перешкоди, пов'язані 3 поглинанням водяної пари, дуже малі, а рівень $\mathrm{CO}_{2}$ відносно постійний. Таким чином, поглинання випромінювання, обумовлене $\mathrm{H}_{2} \mathrm{O}$ і $\mathrm{CO}_{2}$, можна вважати постійним, i цю величину враховувати як поправку і віднімати як постійний зсув. Після проходження потоків оптичного випромінювання через димоповітряне середовище, їх відбивання від досліджуваного середовища і проходження через прошарок в зворотному напрямку, сигнали на

вході і виході оптичної системи матимуть вигляд:

де $-U_{\lambda u}, U_{\lambda 0}-$ сигнали на вході і виході оптичної системи при $\lambda_{u}$ і $\lambda_{0}$ відповідно;

$\xi_{m}$ - випадкова величина, що характеризує шуми в приймально-передавальних каналах.

Отже, для успішної реєстрації величини концентрації речовин в димо-повітряній суміші, необхідно забезпечити наступне співвідношення:

$$
\frac{1 / D}{\xi_{m}}<1
$$

Таке співвідношення досягається при дослідженні спалювання деревини при копченні м'ясних виробів.

Висновки. Рішення завдання з виявлення вмісту димо-повітряних компонентів в повітрі, що утворюються при спалюванні деревини, зводиться до задачі $з$ детектування слідів газоподібних речовин в локальній зоні повітряного середовища. Дане завдання відноситься до числа найбільш складних завдань газового аналізу, що обумовлено малими концентраціями шуканих речовин і навпаки, високим вмістом сполук, що перешкоджають аналізу.

При інтерпретації ІЧ спектрів важливо звертати увагу не тільки на положення максимумів характеристичних смуг, але і на їх інтенсивності, формі, розташуванню щодо інших смуг. Поліпшення чутливості i селективності методу можливо шляхом підвищення роздільної здатності приладів, а також використанням різних прийомів формування та обробки аналізованого сигналу. Одним із прийомів формування аналізованого сигналу є диференційний метод.

Аналогічно до описаного методу виявлення етанолу в димо-повітряній суміші виявляються й інші іiі компоненти, які цікавлять з точки зору правильності проведення копчення м'ясних продуктів, а саме рівень і величина наявності в димо-повітряній суміші формальдегідів, бензойної кислоти, оцтової кислоти, поліциклічних ароматичних вуглеводів, маючих канцерогенні та мутагенні властивості.

\section{References}

1. Britske, M.E. (1982). Atomno-absorbitsionnyy spektrokhimicheskiy analiz [Atomic absorption spectrochemical analysis]. M.: Khimiya. 224 (in Russian)

2. Bal'-Prylypko, L.V. (2010). Tekhnolohiya zberihannya, konservuvannya ta pererobky m"yasa [Technology of meat storage, canning and processing: textbook]. Kyiv (in Ukrainian).

3. Dubyahin, B.V. \& Zhylyakov, D.V. (2018). Udoskonalennya pidkhodiv do zastosuvannya avtomatyzovanykh spektroenerhetychnykh zasobiv v blyzhniy infrachervoniy oblasti spektru [Improvement of approaches to the use of automated spectral energy tools in the near infrared region of the spectrum]. Mizhnarodna naukovo-praktychna konferentsiya «Teoretychni ta prykladni aspekty rozvytku nauky». (pp. 23-26). Kyiv (in Ukrainian).

4. Kross, A. (1961). Vvedeniye v prakticheskuyu infrakrasnuyu spektroskopiyu [Introduction to practical infrared spectroscopy]. M.: Izdatel'stvo inostrannoy literatury (in Russian).

5. Levitskaya, Ye.A. (2011). Razrabotka sistemy skrytoy otsenki psikhofiziologicheskogo sostoyaniya sub"yekta [Development of a system of hidden assessment of the psychophysiological state of the subject]. Vserossiyskoy nauchno-tekhnicheskoy konferentsii studentov, aspirantov i molodykh uchenykh. (188-191). Tomsk (in Russian).

6. Mezenova, O.YA., Kim, I.N. \& Bredimkhin, S.A. (2011). Proizvodstvo kopchenykh pishchevykh produktov [Production of smoked food products]. M.: Kolos (in Russian). 
7. Tarasevich, B.N. (2012). IK spektry osnovnykh klassov organicheskikh soyedineniy [IR spectra of the main classes of organic compounds]. Spravochnyye materialy. M.: MGU (in Russian).

8. Kjallstrand, J., and G. Petersson. (2001). Phenolic antioxidants in alder smoke during industrial meat curing. Food Chemistry 74:85-89.

9. Milly, P.J., R.T. Toledo, and S. Ramakrishnan. (2005). Determination of the minimum inhibitory concentrations of liquid smoke fractions. J. Food Sci. 70(1):M12-M17.

10. Prozrachnost' zemnoy atmosfery. URL:: http://femto.com.ua/articles/part_2/3115.html.-- (data zvernennya 12.08.2021).

11. NIST Chemistry WebBook. URL:: http:// webbook.nist.gov.- data zvernennya 12.08.2021).

\title{
APPLICATION OF ABSORPTION IR SPECTROSCOPY TO DETECT THE COMPOSITION OF THE SMOKE-AIR WOOD BURNING MIXTURES AT SMOKING MEAT PRODUCTS
}

\author{
Oshchypok I.M., Dr. Sci. Tech., Professor \\ Lviv trade and economic University, Lviv, Ukraine
}

The article investigates the prospects of detecting the content of smoke-air components in the air formed during wood combustion. Problems of detecting traces of gaseous substances in the local zone of the air environment are considered. This task is one of the most difficult tasks of gas analysis, due to the low concentrations of the desired substances and, conversely, the high content of compounds that interfere with the analysis. Attention is paid to the interpretation of IR spectra, which consists in taking into account not only the position of the maxima of the characteristic bands, but also their intensity, shape, location relative to other bands. The nature and quantity of a substance in a smoke-air mixture can be judged by the number and position of peaks in the IR absorption spectra, respectively, and by the intensity of these bands by the quantity of the substance (quantitative analysis). Improving the sensitivity and selectivity of the method is possible by increasing the resolution of the devices, as well as the use of various techniques for generating and processing the analyzed signal. One of the methods of forming the analyzed signal is the differential method. The method used must be highly sensitive, accurate, fast and provide selectivity for the detection of components of the smoke-air mixture, and may involve work at some distance. The idea of the method is considered, which consists in simultaneous passage through the smoke-air mixture located in the thermal chamber of probing radiation at two wavelengths, the first of which coincides with the maximum absorption band of the test substance, and the second so-called reference wavelength. the wave is close to the probe, but which does not lie in the absorption band. The ratio of signals at the output of the reference and measuring channels does not depend on the stability of the source and receiver of radiation.

Keywords: smoking, mixture, smoke-air, IR spectroscopy, meat, products

\section{Список використаної літератури}

1. Брицке М.Э. Атомно-абсорбиционный спектрохимический анализ. М.: Химия, 1982. 224 с.

2. Баль-Прилипко Л.В. Технологія зберігання, консервування та переробки м'яса: підручник. Київ, 2010,469 с.

3. Дубягін Б.В., Жиляков Д.В. Удосконалення підходів до застосування автоматизованих спектроенергетичних засобів в ближній інфрачервоній області спектру. Міжнародна науково-практична конференція «Теоретичні та прикладні аспекти розвитку науки». Київ, 11-12 грудня. 2018, С. 23-26.

4. Кросс А. Введение в практическую инфракрасную спектроскопию. М.: Издательство иностранной литературы, 1961, 111 с.

5. Левитская Е.А. Разработка системы скрытой оченки психофизиологического состояния субъекта. Всероссийской научно-технической конференции студентов, аспирантов и молодых ученых. Томск, 2011, С. 188-191.

6. Мезенова О.Я., Ким И.Н., Бредимхин С.А. Производство копченых пищевых продуктов. М.: Колос, 2011, $208 \mathrm{c.}$

7. Тарасевич Б.Н. ИК спектры основных классов органических соединений. Справочные материалы. М.: МГУ, 2012, 55c.

8. Kjallstrand, J., nd G. Petersson. Phenolic antioxidants in alder smoke during industrial meat curing. Food Chemistry, 2001, 74, C. 85-89.

9. Milly P.J., R.T. Toledo, Ramakrishnan S. Determination of the minimum inhibitory concentrations of liquid smoke fractions. J. Food Sci., 2005, 70(1), M12-M17.

10. Прозрачность земной атмосферы. URL:: http://femto.com.ua/articles/part_2/3115.html.- (дата звернення 12.08.2021).

11. NIST Chemistry WebBook. URL:: http:// webbook.nist.gov.- (дата звернення 12.08.2021).

Отримано в редакцію 12.03.2021

Прийнято до друку 02.07.2021
Received 12.03.2021

Approved 02.07.2021 